City University of New York (CUNY) CUNY Academic Works

2019

\title{
The Pedagogies of Cultural Studies
}

Gordon Alley-Young

CUNY Kingsborough Community College

\section{How does access to this work benefit you? Let us know!}

More information about this work at: https://academicworks.cuny.edu/kb_pubs/193

Discover additional works at: https://academicworks.cuny.edu

This work is made publicly available by the City University of New York (CUNY).

Contact: AcademicWorks@cuny.edu 
The Pedagogies of Cultural Studies by Andrew Hickey (ed.) New York, Routledge, 2016 \$49.95/£36.99 (pbk), 221 pp + xvii ISBN: 978-1-138-59808-9.

\begin{abstract}
The Pedagogy of Cultural Studies, edited by Andrew Hickey, seeks to expand understandings of pedagogy beyond the formal classroom to something one practices when doing research, when bringing academia into engagement with the wider society and when engaging in social activism. In examining Cultural Studies pedagogy, the contributors to this book hope to understand how the discipline is currently defined to determine future directions for, and practice in, this field. This review considers the relevance of The Pedagogies of Cultural Studies for those in sport and education. Contributors to this volume varyingly examine how Cultural Studies scholars have educational exchanges with the public beyond academia and the politics of self-other exchanges in Cultural Studies research, as well as issues of multicultural policy, border crossing, supporting disaster/crisis survivors, and gender politics in sport. In keeping with Cultural Studies' aims to explore issues of power and domination in society, this volume has relevance for socio-culturally reflexive educators and those that they serve both in schools and communities.
\end{abstract}

Keywords: Cultural Studies; difference; multicultural education; pedagogy

The socio-cultural aspects of school-based, community, and competitive sport have long been a fertile area of exploration for Cultural Studies in terms of how structures of power, dominance and identity position participants and non-participants in society. For instance, in recent years, the sporting domain has come under increasing scrutiny for seemingly encouraging toxic masculinity (Miller, 2008), xenophobia, and homophobia (Hughson \& Free, 2011). The increased public awareness that comes from this criticism has inspired public information campaigns like the "Kick it Out" campaign in British football, designed to get coaches, officials and fans to rethink their assumptions about race, gender roles, mentoring, and/or leadership (Cleland \& Cashmore, 2014). This increased awareness also comes at a time when the sports industry, thanks in part to a proliferation of media coverage, has never been more financially lucrative (Heitner, 2015; Parrett, 2018). These are issues that are included in Andrew Hickey's edited volume The Pedagogies of Cultural Studies.

Hickey's book begins by examining how Cultural Studies is at a point in its history where it has established itself within the social sciences but, due to comfort, complacency, and/or the corporatization of the modern university, has somewhat strayed from its original intentions of action and of exposing and dismantling structures of dominance, such as those noted above. As a result, Hickey notes that Cultural Studies has of late begun reexamining its assumptions, which has yielded calls to return to the roots of the discipline and for projections of what Cultural Studies should become rather than exploring how it currently exists. Hickey's book explores how 
the pedagogical foundations of Cultural Studies are made clear through examining scholars engaged in doing the work of Cultural Studies inquiry. In other words, by looking at Cultural Studies scholars and what they study it can redefine what is considered to be relevant, and thus allow scholars to reorient the discipline and take it in new directions in the future. The book originated in a symposium held at the University of Southern Queensland in early 2014 convened under the theme Cultural Studies on the Divide; the Pedagogies of Cultural Studies which considered pedagogy as a practice and as a way of reimagining the discipline. The book itself features chapters that, like the symposium that inspired it, frame pedagogy as foundational to the 'doing' of Cultural Studies, as Hickey clarifies:

In taking this approach, this volume asks for a (re)consideration of pedagogy as an opportunity for inquiry, a conceptual apparatus made visible in practice and through which the disposition core to cultural studies might come to be understood and interrogated (p. 4).

Andrew Hickey is an Associate Professor of Communications at the University of Southern Queensland, Australia and his research foci have been critical pedagogy, public pedagogies and emancipatory social practice. For instance, a recent article co-authored by Hickey and colleagues in 2018 examines how an in-school alternative learning program, focused on the repair of old bicycles, allowed students to reconfigure their relationships with their peers, teachers and schooling (Hickey, Myler, \& Smith, 2018). The Pedagogies of Cultural Studies has individual chapters that examine the gender and power dynamics in specific athletic communities (e.g., competitive surfers) and includes studies of how nationally mandated multicultural awareness/inclusion practices should (and should not) ideally be integrated across the curriculum of Australian primary schools. Taken more broadly, the volume explores embodiment, engagement and physically 'doing' Cultural Studies as the key to its pedagogy and, moreover, the pedagogy as key to understanding the discipline. This book's focus on knowing through 'doing' and the embodiment of knowledge, while being reflective of what these processes ultimately teach, certainly resonates with the professional practices of sports, physical, and health educators; whether within schools or broader society beyond the university.

The book has three sections. Section One is organized around the tenet that pedagogies are embodied and lived through their practitioners. This section contains four chapters, the first (written by Hickey) provides a brief orientation to the pedagogies used in Cultural Studies and an overview of the discipline. Chapter 2, authored by Rob Garbutt, a scholar specializing in community engagement, then details an event designed to mark the $40^{\text {th }}$ anniversary of Nimbin Aquarius Softlick - a countercultural festival often given the misnomer of 'Australia's Woodstock' - as a means for examining the self and other on a variety of levels, including the interface between the local university and the community. Following this, in Chapter 3, film studies scholar Linda Wight examines her practice of teaching critical perspectives on 
masculinities and race via science films like District 9, while reflecting on how her own feminist body is implicated in this curriculum. In the final chapter of this section, Baden Offord, considers how pedagogy activates its participants in ways that carry ethical implications. Offord speaks from an Indigenous standpoint, as a Māori Pākehā, a perspective that could perhaps have been fostered more within this volume.

Section Two of the book considers the ways that the self and cultural other come to recognize and learn through each other in pedagogical exchanges. The scholars in this part of the book ask where our authority as researchers/teachers comes from. They discuss how the assumptions that result from such positions of authority can lead us to treat our students, and our research participants, in disempowering rather than democratic ways. This section starts with Chapter 5, authored by surfer, poet, performer, writer, and academic Kim Satchell, who uses objects found on a beach walk to consider a pedagogical exchange with the ecosystems that we regularly (and often unreflectively) engage with for sport and leisure. The penultimate chapter in Section Two is by Amanda Third, a research fellow in digital, social and cultural research whose work looks at Cultural Studies scholars who divide their careers between working for universities, government and/or industry. This chapter examines what Cultural Studies scholars can learn from their work experiences outside of universities, in order to foster more interaction between academia and the public sector/government. Notable within Section Two is Chapter 7, where Lisa Slater, for whom a primary research interest is cultural exchanges between Indigenous and European Australians, examines how a problematic ethic of benevolent, guiltassuaging care has come to characterize White Australian's relationships with Aboriginal Australians. Slater considers how White educators' seemingly benevolent or pro-diversity perspectives can replicate these historical dynamics or reconstruct new, yet still disempowering, dynamics. This last chapter is recommended for any educator working in a cultural context still shaped by a colonial past or a past characterized by intercultural misunderstanding.

Section Three of Hickey's book is focused on considering the role that space and place play in shaping the pedagogical exchange. Megan Watkins, whose research foci include cultural analysis of education and rethinking multicultural education, begins this section with Chapter 8 , where she explores two examples of how multicultural education policies mandated by New South Wales had been implemented. Watkins considers how local teachers in two different community schools interpret new multicultural education policies and then create curricula to reflect these polices. Watkins impresses that often the efforts to foster multiculturalism end up being positioned unreflexively as an 'add-on' to the curriculum that imparts cultural trivia for a specific cultural day or event. 'Add-on' thinking, Watkins argues, only fosters tolerance or civility (akin to Slater's notion of 'White care' - Chapter 7) but not the cultural understanding that comes from looking at multicultural education holistically, reflexively and, sometimes, contentiously. Chapter 8 also speaks to the need for governmental officials who oversee statefunded schools and design teacher professional development programs that require teachers to 
implement multicultural education practice, to first gauge the capacity of their teachers to undertake such work.

Also notable in Section Three is Chapter 11, authored by Rebecca Olive, exploring her embodied experiences as a woman in the male dominated world of surfing. Olive argues that female surfers are perceived, communicated about and represented publicly in ways that highlight their sexual appeal and subjugate their sporting efforts in comparison to male surfers. This is especially relevant to all educators but especially to physical educators and sports coaches seeking to support female athletes and foster 'forward thinking' male athletes. Olive highlights the different knowledge and voices yielded by studying a sporting community via observation versus participating in it as a surfer and a blogger. Of the women she surfed with in her study, Olive argues:

Their presence and behavior incite cultural pedagogies, presenting experiences and relationships through which the surfers around them can begin to rethink their assumptions about what surfing is and can look like, and how women can fit into that (p. 192).

Gregory Martin and Andrew Hickey's chapter (Chapter 9) exploring 'do it yourself' pedagogies that they undertake to re-orientate Cultural Studies politically and ethically, taking lessons from storytelling as a participatory, dialogic, and future-oriented process is also a significant read within this section. It seeks to encourage educators to examine the implications of how they engage their students, while also reflecting on the future development of their own professional practice. For Katrina Schlunke in Chapter 10, it is the experience of having her house burn down in a natural disaster that prompts her to re-orientate her own Cultural Studies methods/pedagogy and examine how scholars in the discipline approach the constructs of charity and suffering. This places Schlunke as a subject in her own study of what it is to survive a disaster and to be in the position of receiving, rather than giving, charity after having lost many of her belongings in the fire. This section, and indeed the book, concludes with a final chapter by Hickey which explores what a signature pedagogy of Cultural Studies might look like. Instead of specifying specific methods or practices, Hickey describes the qualities of this practice as one meaningfully engaged with culture, the environment, being human and of relating to one's colleagues/peers in significant ways. The signature pedagogy Hickey describes is centered on criticism and critique but also on exposure and conscientization (i.e. making hegemony and unconscious submission to dominant ideology evident). Moreover, it is concerned with being in constant evolution in response to changing contexts and self and yet clearly aware of the intent of its explorations.

The Pedagogies of Cultural Studies is a worthwhile read for educators across all age groups both within and outside of formal educational settings and especially for those pursuing professional development. Moreover, it holds value for those studying for advanced degrees in sociology/Cultural Studies of sport, exercise, health, and/or recreation. As noted, this text emerged from an Australian Cultural Studies symposium and the contributing scholars largely 
write about Australian contexts; yet, the insights shared are applicable to readers in the US, Canada, the UK and beyond. The chapters can be approached as stand-alone readings for those with varying interests in Cultural Studies pedagogy; from those seeking accessible but thoughtprovoking school-based case studies of multicultural education in practice (e.g. Chapter 8) to those seeking philosophical and post-structural reflections on Cultural Studies and pedagogies in conversation different elements/subjectivities (e.g. Chapter 5). At several places in this book the point is made that Cultural Studies must do a better job of communicating and building meaningful relationships with the worlds both within and beyond academia. This is a challenge that will resonate with many health and physical educators for whom sport and physical activity have long been a means for engaging the community in significant dialogue on a range of prosocial issues.

\section{References}

Cleland, J., \& Cashmore, E. (2014). Fans, racism and British football in the twenty-first century: The existence of a 'colour-blind' ideology. Journal of Ethnic \& Migration Studies, 40(4), 638-654. https://doi.org/10.1080/1369183X.2013.777524

Heitner, D. (2015, October 15). Sports industry to reach $\$ 73.5$ billion by 2019. Forbes. Retrieved from https://www.forbes.com/sites/darrenheitner/2015/10/19/sports-industry-to-reach-735-billion-by-2019/\#61c560091b4b

Hickey, A., Myler, T., \& Smith, C. (2018). Bicycles, 'informality' and the alternative learning space as a site for re-engagement: a risky (pedagogical) proposition? Asia-Pacific Journal of Teacher Education, DOI: 10.1080/1359866X.2018.1504281 https://doi.org/10.1080/1359866X.2018.1504281

Hughson, J., \& Free, M. (2011). Football's “coming cut": Soccer and homophobia in England's tabloid press. Media International Australia, (140), 117-125. https://doi.org/10.1177/1329878X1114000115

Miller, K. E. (2008). Wired: Energy drinks, jock identity, masculine norms, and risk taking. Journal of American College Health, 56(5), 481-489. https://doi.org/10.3200/JACH.56.5.481-490

Parrett, G. (2018, June 7). European football market worth a record $€ 25.5$ billion ( $£ 21.9 \mathrm{bn})$ as Premier League leads the way in new era of financial stability. Deloitte. Retrieved from https://www2.deloitte.com/uk/en/pages/press-releases/articles/annual-review-of-footballfinance-2018.html 
Gordon Alley-Young, Kingsborough Community College - CUNY

Gordon.Young@kbcc.cuny.edu 